\title{
Afganistan Uyruklu İlkokul Öğrencilerinin Gözüyle Vatanseverlik
}

\section{Patriotism Through the Eyes of Afghan Primary School Students in Turkey}

\author{
Mehmet Zeki GÖKSU, Sorumlu Yazar, Dr. Öğr. Üyesi. \\ Erzincan Binali Yıldırım Üniversitesi, İlahiyat Fakültesi, Türkiye. \\ zeki.goksu@erzincan.edu.tr \\ http://orcid.org/0000-0003-0875-2226
}

ISSN: 1303-880X

e-ISSN: 2667-7504 http://ded.dem.org.tr

Makale Türü / Article Type: Araştırma Makalesi / Research Article Geliş Tarihi / Received Date: 29.07.2019 Kabul Tarihi / Accepted Date: 01.05.2020 Yayın Tarihi / Published Date: 25.06.2020

Tr/En: $\mathrm{Tr}$

Intihal / Plagiarism: Bu makale, en az iki hakem tarafindan incelendi ve intihal içermediği teyit edildi. / This article has been reviewed by at least two referees and scanned via a plagiarism software.
Atıf/Citation: Göksu, M. Z. (2020). Afganistan uyruklu ilkokul öğrencilerinin gözüyle vatanseverlik. Değerler Ĕ̈itimi Dergisi, 18(39), s.33-63. https://doi.org/10.34234/ded.598196 
Öz: Vatanseverlik, üzerinde yaşanan toprağa içindekilerle birlikte duyulan sevgi ve minnetin adıdır. Araştırmanın amacı, Erzincan İl merkezinde ikamet edip ilkokullarda öğrenim gören Afgan mülteci öğrencilerin vatanseverlik anlayışlarının tespit edilmesi ve halihazırda yaşadıkları ülke olan Türkiye'ye karşı vatan algılarının tespitidir. Nitel araştırma yöntemlerinden durum çalışması olan araştırmanın evreni, 2018-2019 eğitim-öğretim y1lında Erzincan Cahit Ziya Ulukök ve Hayrettinpaşa İlkokullarında okuyan Afgan mülteci öğrencilerdir. Çalışma grubu ise amaçlı örneklem stratejisiyle tespit edilen toplam on altı öğrencidir. Veri toplama tekniği olarak odak grup görüşmesi, veri toplama arac1 olarak ise yarı yapılandırılmış görüşme formu kullanılmıştır. Sonuçlar, betimsel analiz yöntemiyle değerlendirilmiştir. Öğrencilerin açıklamaları ve çizimleri; Güzel Okulum, Türk Bayrağı ve Özgür/Güçlü Türkiye olarak üç alt temada toplanırken vatanseverlik tarifleri ise vatan için şehit olmak, vatan için görevini yapmak, Türkiye yi sevmek şeklinde üç alt temada toplanmıştır. Afganlı öğrencilerin öz vatanlarına karşı sevgilerinin, Afganistan doğumlu olmamaları ve oraya ait yaşanmış bir anıları olmamasından, kaybolmaya başladığı, zorunlu sebeplerle Türkiye 'ye göç ettikleri, Türkiye'de ki iyi eğitim, rahat yaşam vb. imkânlar ile okuldaki karşılaştıkları olumlu tutumlar sebebiyle mutlu oldukları, Türk halkına ve Türkiye 'ye karşı ziyadesiyle olumlu duygular besledikleri, öğrencilerin büyük çoğunun Türkiye yi ana vatan olarak benimsemeye başladıkları araştırma sonucunda ulaşılan en önemli bulgulardandır.

Anahtar Kelimeler: Eğitim, Değer, Vatanseverlik, İlkokul, Mülteci.

$\&$

Abstract: The aim of the research is to investigate the patriotic understanding of Afghan refugee children and to discover their perception of patriotism towards their homeland and their host country. It is a case study. The population of the study consists of Afghan refugee students studying at Cahit Ziya Ulukök and Hayrettinpasa Primary Schools in Erzincan province 2018-2019 academic year. The study group consists of 16 students. Focus group interview and semi-structured interview form was used. The data were evaluated with descriptive analysis method. Drawing and explanations of students such as; my beautiful school, Turkish Flag, and free/strong Turkey. The definition of patriotism, becoming a martyr for the motherland, doing one's duty for the motherland, love for Turkey are grouped into three sub-themes. We have found out that Afghan students' have forgotten their own cultural identity thus have no sense of attachment to their homeland since they were not born in Afghanistan and also memories rela- 
ted to Afghanistan seem to be absent. Results indicate that they lead a peaceful life in Turkey due to the effective training and education that the host country provided them. All in all, they have positive feelings about Turkey and the Turkish people. Also it should be added that Afghan students in question have begun to embrace Turkey as their homeland.

Keywords: Education, Value, Patriotism, Primary school, Refugee.

(The Extended Abstract is at the end of the article)

\section{Giriş}

Değer, günlük dilde kıymetli, pahalı, sıradan olmayan şeylere (Türk Dil Kurumu, 2019) söylenildiği gibi kavram olarak; hikmetli, anlamlı, faydalı, gerekli davranış ve tutumlar (Balcı, 2014, s.133) olarak açıklanmaktadır. Değerler, davranışlara yön veren temel ilkelerdir (Crick, 2012) ve istenmeyen davranışa karşı kişisel ve sosyal olarak tercih edilen davranışa son halini veren ya da özel bir ruh hali oluşturan güçlü bir inanç sistemidir (Rokeach, 1973, s.5). Dolay1sıyla değere, kıymet atfeden insan ve toplum hayatıdır. Çünkü insan, değerlerini ilişki içinde olduklarıyla oluşturur ve sergüzeşt-i hayatı kapsamında edindiği tecrübeler sonucunda değer kavramına bir anlam kazandırır (Bolay, 2013, s.60). İnsan davranışları değerleriyle şekillenir. Kişi, edindiği değerlere uygun davranış ve tutum geliştirir (Kaymakcan, 2012, s.13).

Her çağda/toplumda değerler kendine özgüdür ve bu değerleri yorumlama, anlama tarzı farklıdır. Bununla birlikte değerler ve toplumun değerleri anlama biçimi de zamanla değişmektedir. Geleneksel dönemde sosyal değerleri ilahi/ aşkın olması ve yaşanan tecrübeler belirlerken, modern dönemde akla uygun olması belirler. Postmodern döneme gelindiğinde ise, belirleyici unsur arzulardır. Bu yüzdendir ki, geleneksel ve modern dönemde -kaynakları farklı olsa da- bir kesinlik varken, Postmodern dönemde ise muğlaklık, kesinliğin yerini almıştır (Yazıc1, 2013).

Kimilerine göre günümüz insanının kendi öz değerlerine yabancılaşması ve kendisini bu öz değerlerin etki alanından çıkararak yerine başka değerler inşa etmesi son dönemlerin en önemli problemidir. Çünkü bireyin öz değerlere aykırı duygu, düşünce ve davranışlarda bulunması, kendisini suçlu hissetmesine, kendisine ve başkalarına güvensizlik duymasına neden olmaktadır (Kandemir, 2019, s.1). Bu bakımdan birey ve toplum hayatının temelini oluşturan öz değer- 
lerin doğru ve anlamlı bir şekilde inşa edilmesi, öz değerlerden sayılabilecek olan vatan sevgisinin de bu doğrultuda öğretilmesi önem kazanmaktadır.

Vatan sevgisi, toplumları, kültürleri bütünleştirecek potansiyelde bir sevgi türüdür (Ergen, 2006, s.150). Conover ve Feldman’a göre vatanseverlik; "His dünyasında milletine derin ve duygusal bir bağl1lıktır". Kosterman ve Feshbach ise vatanseverliği "Milletine karşı hissettiği bir gurur ve sevgi derecesidir." şeklinde tanımlamışlardır (Huddy ve Khatib, 2010).

Vatandaşlık kavramı, vatanseverlik hususu ele alındığında üzerinde durulması gereken önemli bir kavramdır. Çünkü bu kavram birey-devlet arasındaki ilişkiyi tanımlamak için kullanılır. Vatandaşlıkta hukuki bağlar kadar siyasi bağlar da önemlidir. En genel anlamda bireyin hak ve sorumlulukları ile devletin zorunlu bir kurum olduğuna işaret eder Özellikle toplumsal vatandaşlık anlayışını benimseyen toplumlar, çocuklarına sahip oldukları diğer değerlerle beraber devlet ve toplumu önceleyen vatanseverlik anlayışını de kazandırma eğilimindedirler. (Nazıroğlu, 2013, s.32; 48). Çoğulcu toplumlarda düşmana karşı vatanı savunmak, ancak sevgi ve sadakatle mümkündür. Bu eğitimin genç yaşlarda verilmesi daha uygundur (Güngör 1997, s.160).

Vatanseverlikle yakından ilişkili diğer bir kavram ise "ulusçuluk" 'tur. Toplumsal inşa sürecinde insanları bir arada tutacak ve aidiyet hissi oluşturacak modern devlet ideolojisinin adı ulusçuluktur. Ulusçuluk, henüz var olmayan bir ulusun belirli aşamalar sonucunda var edilmesidir(Zabunoğlu, 2018). Etnik ve vatandaşlığa dayalı ulusçuluk olmak üzere iki tür ulusçuluktan söz edilebilir. Etnik ulusçuluk; ulusu, objektif unsurlarından mürekkep kabul eder. Onun dışındakileri dışlar ve ötekileştirir. Vatandaşlığa dayalı ulusçuluk ise siyasal sınırlar dışında kalan herkesi, devlet tarafından ortaya konulan "üst değerler" etrafında toplayan "herkese açık sübjektif bir ulusçuluk anlayışıdır”(Nazıroğlu, 2013, s. 37). Bu bağlamda "Türkiye deki mevcut ulusçuluk fikri nedir?" diye bir soru sorulacak olursa; "Ne mutlu Türküm Diyene" söylemi üzerinden pratikte zaman zaman etnik vatandaşlığı çağrıştıran görüşlere (Uluçevik, 2013) rastlansa bile, devlet düzenini oluşturan kurallar $^{1}$ dikkate alındığında vatandaşlığa dayalı ulusçuluk tanımına daha yakın olduğu söylenebilir.

Yurttaşlık bilgisinin öğrenilmesinin anlamı, ülkesinin legal ve politik sistemiyle birbirini bulan bilgi, tutum, inanç ve davranışların elde edilmesidir. Geleneksel olarak vatanseverlik eğitimi sadece sinfflarda ve derslerdeki tarihsel ve sosyal dersleri kapsar. Kapsamlı bir değerler eğitimi içindeki vatanseverlik

1 Bkz: Türkiye Cumhuriyeti Anayasası`nın 66. Maddesi. 
eğitimi ise okulda geçen zamanın daha fazlasını kapsar (Kirschenbaum, 1995, s.24). Yani Vatanseverlik eğitimi sadece okul içinde ders olarak verilecek bir değer değil, okul dışı zamanları da kapsayan sürekli bir eğitimin parçası olmalıdır.

Sosyolojik bir gerçeklik olan göç, insanların sosyal, ekonomik, siyasi nedenlere bağlı olarak ya da tabiat şartlarının yaşam kalitesini etkilemesi gibi nedenlerle yurt tutmak için coğrafi olarak yer değiştirmesi şeklinde tanımlanabilir. (Akınc1, Nergiz, Gedik, 2015; sozluk.gov.tr, 2020.) İnsanlar bazen iş aramak, çalışmak ve daha rahat bir hayata kavuşmak, daha iyi bir eğitim almak için isteyerek doğup büyüdükleri topraklardan ayrılırken; bazen de sürgün, savaş, baskı ya da doğal afet gibi mücbir sebeplerle hayat mücadelesini sürdürmek için yaşadıkları yerlerden göç etmektedir.

Günümüzde, sosyoekonomik motivasyonlar göçün en yaygın nedenleri arasındadır (Hanson, 2018). Birleşmiş Milletler Mülteciler Yüksek Komiserliği ve Norveç Mülteci Konseyi için düzenlenen "Zincirin kırılması Afgan Mültecileri için Gelecek ve Eğitim raporunda, Afganistan ’dan göçün sebepleri ve göçmenlerin göç ettikleri ülkelerdeki durumları hakkındaki tespitler çarpıcıdır. Rapora göre; Taliban rejiminin 2001 yılında devrilmesinden sonra özellikle eğitim alanında ülkede ciddi gelişmelerin görüldüğü, fakat hala 3.500 .000 çocuğun okula gidemediği, bunun önünde -özellikle kız çocukları için- kültürel baskı unsurları, fakirlik, kalitesiz eğitim gibi engellerin bulunduğu ifade edilmektedir. Raporda ayrıca İran ve Pakistan`da bulunan Afgan mülteci ailelerine ait çocukların, yerel okullara kabul edilseler bile, ciddi zorluklarla karşılaştıkları ifade edilmiş, Afgan kız çocuklarının eğitim konusunda talep ve istekleri ne de yer verilmiştir. Örneğin, Pakistan`da ikamet eden Afgan mülteci genç bir kız öğrencinin eğitim konusunda söylediği "Eğitim bir 1şıktır. Onsuz biz sonsuza kadar karanlıkta kalır ve kör oluruz." sözü raporda flaş cümle yapılarak bu duruma dikkat çekilmiştir (Jenner, 2015, s.3-6).

Göç ister gönüllü ister zorunlu olsun, göç alan ve göç veren toplumlar için sadece fizikî ve coğrafi bir yer değiştirme değil, hayatın tamamını kuşatan, insan-mekân ilişkilerinin yeniden inşasını sağlayan bir olgu olarak değerlendirilmelidir (Adıgüzel 2016, s.483). Özellikle yirminci yüzyılın ikinci yarısında azgelişmiş veya gelişmekte olan devletlerde sosyal, ekonomik ve çevresel sorunların sonucu olarak ortaya çıkan kalitesiz eğitim, açlık ve doğal afetler önemli toplumsal sorunlara neden olmuştur (Bates, 2002; Black, 2014, s.1-4; Börü ve Boyac1, 2016). Öte yandan bu durum, göçe maruz kalan ülkelerde birtakım düzensizliklere neden olurken (Topçuoğlu, 2012) birçok sektörde, özel- 
likle eğitimde, aşılması zor krizler ortaya çıkarmıştır. Bu bağlamda Afganistan'da meydana gelen terör eylemleri ve ekonomik gerileme nedeniyle, binlerce Afgan göçmen grubu son yıllarda İran üzerinden Türkiye'ye göç etmektedir. Göç İdaresi Genel Müdürlüğü nün düzensiz göç İstatistiklerini yayınladıklar1 tablolara bakıldığında, özellikle 2017 yılından sonra (2017 yılı 45.259 kişi, 2018 y1lı 100.841 kişi, 14.08.2019`a kadar 88.394 kişi) Afganlı mültecilerin düzensiz bir şekilde Türkiye ye göç etmelerinde ciddî anlamda bir artış olduğu görülmektedir². BBC Türkiye 'nin 6 Nisan 2018 tarihli haberine göre; son 3 ayda 25 binden fazla mülteci İran üzerinden Türkiye'ye kaçak giriş yapmıştır. ${ }^{3}$ Göç eden Afganistanlı mültecilerin yaklaşık iki bini de Erzincan'da ağırlanmaktadır. ${ }^{4}$ Mültecilerin okul çağındaki çocukları ise halk eğitim merkezleri iş birliği yapılarak, Türkçe dil kursları da dahil olmak üzere, dahil edildikleri oryantasyon programlarının ardından yaşları ve akademik seviyelerine göre devlet okullarına kaydedilmektedir. Afgan öğrencilerin tamamı, yaşadıkları bölgelerdeki okullara kabul edilmekte, aynı sınıf ortamında yerli öğrencilerle eğitim almaktadırlar.

Göç vakası, ya mağdurların bazı ulusal değerlerini kaybetmelerine neden olmakta, ya da vatanseverlik gibi ulusal değerlerin duygusunu ve bilincini son derece güçlü kılmaktadır. Bu çalışma ile Erzincan`da ilkokulda öğrenim gören Afganistan uyruklu mülteci öğrencilerin vatanseverlik değerlerinin ortaya konulmasına ve halihazırda yaşamlarını sürdürdükleri ülke olan Türkiye'ye karşı olan vatan algılarının tespit edilmesine çalışılmıştır.

\section{Yöntem}

Bu bölüm, araştırma deseni, çalışma grubu, veri toplama tekniği ve aracı, verilerin toplanması ve analizi bağlamında bazı temel bilgilerden oluşmaktadır.

\section{Araştırmanın Deseni}

İlkokullarda öğrenim gören Afgan mülteci öğrencilerin vatanseverlik değerlerinin belirlenmesini ve mevcut durumda yaşadıkları ülke olan Türkiye'ye karşı olan vatan algılarının tespit edilmesini amaçlayan bu araştırma nitel araştırma

\footnotetext{
2 Bkz: www.goc.gov.tr

3 Bkz: www.bbc.com

4 Erzincan Göç idaresi İl Müdürlüğünden resmi yazı ile Erzincan`da ikamet eden Afgan mülteci sayısı talep edilmiş, ancak gizli bilgi olması sebebiyle talebimiz reddedilmiştir. Ancak alınan sözlü bilgiler ve yapılan araştırmalar sonucunda Erzincan`da yaşayan Afgan mültecilerin sayısının 2000 kişi civarında olduğu düşünülmektedir.
} 
yöntemdir. Bu yöntem, şemsiye bir kavram olarak eylem araştırması, durumsal araştırma, kültür analizi, içerik analizi ve betimsel analiz gibi bir dizi farklı yaklaşımı içine alır (Yıldırım ve Şimşek, 2013, s.45). Bu araştırmanın deseni, durum çalışmasıdır. Kısaca tanımlamak gerekirse durum çalışması, kendi yaşam alanı içinde güncel bir olguyu çalışan görgül bir yöntemdir (Yıldırım ve Şimşek, 2013, s.313). Durum çalışmalarının odağ belirli bir program, olay ya da olgudur. Sonuçlar detaylı bir şekilde tanımlanır (Merriam, 2013, s.43, 44). Derinlemesine görüşmeler, katılımc1 gözlemleri ve doküman topluma şeklinde elde edilen verilerin derinlemesine ve boylamsal olarak analiz edilmesidir. (Glesne, 2013, s.30). Ayrıca iyi bir durum çalışması vakayı net bir şekilde belirler ve betimler, temalar belirlenerek analiz sonuçlarından çıkarımlar elde edilir (Creswell, 2013, s.264). Araştırma kapsamında yukarıda belirtilen hususlara dikkat edilmiş ve adım adım uygulanmaya çalışılmıştır.

\section{Çalışma Grubu}

Araştırmanın evrenini 2018-2019 eğitim-öğretim yılı Erzincan il merkezinde faaliyet gösteren Cahit Ziya Ulukök İlkokulu ve Hayrettinpaşa İlkokullarında okuyan Afgan mülteci öğrencilerdir. Çalışma grubu bu öğrenciler arasından amaçlı örneklemler stratejisiyle seçilen toplam on altı öğrenci oluşturmaktadır. Amaçlı örneklemler stratejisi araştırmacının bireyleri ve çalışma mekânlarını seçmesi anlamına gelir. Çünkü bu kişiler çalışma probleminin çalışmanın merkezi olan fenomenin anlaşılması için kendi iradeleriyle bilgi verebileceklerdir (Creswell, 2013, s.156). Nitel araştırmalarda örneklem büyüklüğünü tespit için belirlenmiş bir kural yoktur. Çünkü araştırmanın geçerlilik ve anlamlılık derecesi, örneklem büyüklüğüyle değil, elde edilen verilerden alınan bilgiye ve araştırmacının verileri elde edebilmesine ve bunları yorumlama becerisiyle ilgilidir (Patton, 2014, s.244-245). Bu bakımdan yeterli ve doğru veri elde etmek için amaçlı örneklem stratejisi benimsenmiş; Türkçeyi iyi konuşabilen ve söylenenleri anlayabilen, sekizer öğrenciden oluşan iki grup oluşturulmuş ve toplamda on altı öğrenci ile çalışma gerçekleştirilmiştir. Amaçlı örneklem stratejisinin seçilme sebebi, evreni temsil eden katılımcıların belirlenmesinde özel bilgi ve deneyimlerin kullanılmasına (Berg ve Lune, 2015, s.71) firsat tanıma düşüncesidir. 


\begin{tabular}{lllll}
\hline \multicolumn{5}{l}{ Tablo 1: Çalışma Grubuna Dair Bazı Temel Bilgiler } \\
\hline No & Rumuz & Cinsiyet & Sinıf & Okulu \\
\hline 1 & Ö1 & Kız & 4 & Cahit Ziya Ulukök İlkokulu \\
\hline 2 & Ö2 & Kız & 4 & Cahit Ziya Ulukök İlkokulu \\
\hline 3 & Ö3 & Kız & 3 & Cahit Ziya Ulukök İlkokulu \\
\hline 4 & Ö4 & Kız & 3 & Cahit Ziya Ulukök İlkokulu \\
\hline 5 & Ö5 & Erkek & 3 & Cahit Ziya Ulukök İlkokulu \\
\hline 7 & Ö6 & Erkek & 3 & Cahit Ziya Ulukök İlkokulu \\
\hline 8 & Ö7 & Erkek & 2 & Cahit Ziya Ulukök İlkokulu \\
\hline 9 & Ö9 & Erkek & 2 & Cahit Ziya Ulukök İlkokulu \\
\hline 10 & Ö10 & Kiz & 2 & Hayrettinpaşa İlkokulu \\
\hline 11 & Ö11 & Erkek & 2 & Hayrettinpaşa İlkokulu \\
\hline 12 & Ö12 & Kız & 2 & Hayrettinpaşa İlkokulu \\
\hline 13 & Ö13 & Erkek & 2 & Hayrettinpaşa İlkokulu \\
\hline 14 & Ö14 & Kız & 2 & Hayrettinpaşa İlkokulu \\
\hline 15 & Ö15 & Kız & 2 & Hayrettinpaşa İlkokulu \\
\hline 16 & Ö16 & Erkek & 4 & Hayrettinpaşa İlkokulu \\
\hline & & & &
\end{tabular}

\section{Veri Toplama Tekniği ve Aracı}

Araştırma veri toplama tekniği, odak grup görüşmesidir. Bu tekniğin kullanılmasında amaçlanan fayda ise; katılımcıların diğer katılımcılarla eşzamanlı, seri ve özgün bir şekilde kendi görüşlerini söylemelerini sağlamak, diğer katılımc1larla etkileşim halinde fikirlerini beyan etmelerini temin etmek ve kaliteli veri elde etmektir (Bkz. Berg ve Lune, 2015, s.189-190; Glesne, 2013, s.177; Patton, 2014, s.386).

Araştırmanın veri toplama aracı ise araştırmacı tarafından hazırlanmış açık uçlu altı sorudan ibaret yarı yapılandırılmış görüşme formudur. Yine öğrencilerin görüşlerini farklı tarzda ifade edebilmelerini sağlamak amacıyla, görüşme esnasında kendilerine dağıtılan kâğıtlara vatanseverliği anlatan resim yapmaları istenmiştir. Dokümanlar, görüşme sonrasında araştırmada yer verilebilmesi için öğrencilerden alınmıştır (Bkz. Berg ve Lune, 2015, s.205-206).

\section{Verilerin Toplanması}

Araştırma verilerinin toplanması amacıyla söz konusu okullarda uygulanan odak grup görüşmeleri kamera ile kayıt altına alınmıştır. Görüşme başlarken katı- 
lımcılara araştırmanın amacı, odak grup görüşmesinin genel kuralları hakkında bilgi verilmiş; bu anlamda gönüllük esasına göre katılımın sağlandığı, elde edilen veriler rumuz isimlerle araştırmada kullanılacağı, görüntülerin hiçbir şekilde herhangi bir yayın ortamında yayınlanmayacağı ve hiç kimseyle paylaşılmayacağı, cevapların doğru ya da yanlış şeklinde kategorize edilmeyeceği, sorulan sorulara samimiyetle cevap verilmesinin beklendiği belirtilmiştir. Görüşme kayıtları transkripsiyon ve analize tabi tutulmuş, kayıtlar yedekli olarak saklanmıştır.

\section{Verilerin Analizi}

Kamera kayıtları transkripti sonucu yazılı hale dönüşen veriler, NVIVO 11 PLUS programı yardımıyla analiz edilmiştir. Görüşmeler, betimsel analiz yöntemi kullanılmış, veriler oluşan temalara göre özetlenmiş ve yorumlanmıştır (Yıldırım ve Şimşek, 2013, s.256). Betimsel bulgular, analizler ve üzerinde odaklanılan her bir yorum, kısa ve öz şekilde ortaya konulmuştur (Patton, 2014, s.511).

\section{Geçerlik ve Güvenirlik}

Araştırmada geçerlik sağlanması için gerekli tedbirler alınmıştır. Bu sebeple veri toplama aracı yarı yapılandırılmış görüşme formu hazırlanırken alan ve eğitim araştırmaları uzmanı toplam yedi kişiye gönderilerek alınan dönütler çerçevesinde gerekli iyileştirmeler yapılmıştır. Görüşme formu içeriğindeki soruların, yönlendirme içermeyen, katılımcının anlayacağ ${ }_{1}$ sadelikte ve açık uçlu olmasına dikkat edilmiş, ayrıca araştırma yapılacak okullardan seçilen beş öğrenci ile formlar test edilmiş, tartışılmış ve gerekli iyileştirmeler sonucunda form kullanılabilir hale getirilmiştir.

\section{Bulgular}

Bu bölüm, öğrencilerin odak grup görüşmesi sırasında verdikleri cevaplardan elde edilen bulgular ve bu bulgulara dair yorumlardan oluşmaktadır. 


\section{Öğrencilerin Türkiye`deki İkamet Süreleri}

Şekil 1: Afgan Uyruklu Öğrencilerin Türkiye`de İkamet Süreleri

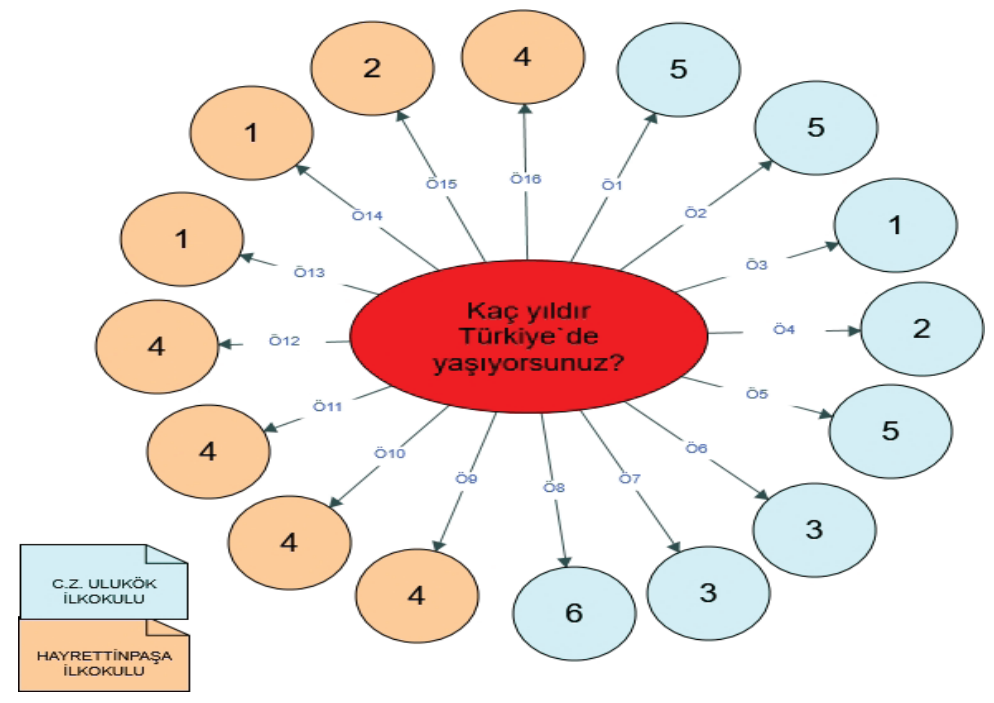

Şekil 1 'de görüldüğü üzere Afgan uyruklu öğrencilere "Kaç yıldır Türkiye'de yaşıyorsunuz?” diye sorulduğunda; 3 öğrenci 1 y1l (Ö3, Ö13, Ö14), 2 öğrenci 2 y1l (Ö4, Ö15), 2 öğrenci 3 y1l (Ö6, Ö7), 5 öğrenci 4 y1l (Ö9, Ö10, Ö11, Ö12, Ö16), 3 öğrenci 5 y1l (Ö1, Ö2, Ö5), son olarak 1 öğrenci ise 6 y1l (Ö8) süreyle Türkiye' de yaşadıklarını beyan etmişlerdir. Görüldüğü üzere öğrencilerin büyük çoğunluğu 3 yıl ve üzerinde Türkiye'de ikamet etmektedir.

\section{Öğrencilerin Türkiye ye Göç Etme Nedenleri}

Öğrencilere Türkiye ye göç etme nedenleri sorulduğunda öğrencilerin yarıs1 (Ö1, Ö2, Ö7, Ö8, Ö9, Ö10, Ö13, Ö15) savaş sebebiyle göç ettiklerini ifade etmişlerdir. Ayrıca cevaplarının bir kısmında 9 öğrenci (Ö3, Ö4, Ö5, Ö11, Ö12, Ö13, Ö14, Ö15, Ö16) eğitim için Türkiye ye göç ettiklerini, 1 öğrenci (Ö3) babasının hastalı̆̆ı sebebiyle Türkiye'ye göç ettiklerini beyan etmişlerdir. Bununla birlikte öğrencilerin göç serüveni sırasında İran 'da bir süre ikamet ettiklerini, burada kendilerine okuma firsatı verilmemesi ve İran devleti tarafindan Afganistan`a geri gönderilmek istenmeleri (Ö5, Ö16) sebebiyle Türkiye’ye geldiklerini beyan etmeleri dikkat çekicidir. Yine Ö16 'nın “Afganistan'da eğitim seviyesi düşük, orada kadınlar tek başına dışarı çıkamıyorlar, ayrıca okulda medeni eğitim verilmiyordu, dinî eğitim veriliyordu..." diyerek göç nedenini Afganistan 'daki kadınların sosyal hayattaki yerlerinden rahatsızlık duymaları 
ve bunu eğitim seviyesinin düşüklüğüyle açılaması ve sadece dini eğitim verilmesinden dolayı Afganistan eğitim sisteminden rahatsız olması göz önüne alınması gereken bir durumdur.

\section{Öğrencilerin Türkiye`de Mutluluk Nedenleri}

Öğrencilere Türkiye'de yaşamaktan mutlu olup olmadıkları ve mutluluk nedenleri sorulduğunda öğrencilerin tamamı mutlu olduklarını beyan etmişlerdir. Mutlu olma nedenleri sorulduğunda; güzel bir ülke olmas1 (Ö1, Ö2, Ö3, Ö4, Ö5, Ö6, Ö9, Ö10, Ö11, Ö12, Ö13, Ö14), iyi insanların olmas1/ayrım yap1lmamas1 (Ö1, Ö2, Ö3, Ö12), eğitim almalar1 (Ö5, Ö6, Ö7, Ö8, Ö10, Ö11, Ö12, Ö13, Ö14, Ö15, Ö16) emniyetli bir ülke olmas1/savaş olmamas1 (Ö4, Ö9, Ö10, Ö11, Ö12, Ö13, Ö15, Ö16) şeklinde ifade etmişlerdir. Öğrenci cevaplarından örnekler incelendiğinde Ö1; “Çok mutluyum, çünkü Türkiye çok güzel bir yer. İnsanları çok iyi. Okul müdürümüz, öğretmenimiz bize çok iyi davranıyor. O sebeple Türkiyesyi seviyorum.” dediği, diğer öğrencilerin de kafa sallayarak arkadaşlarını tasdik ettikleri, Ö16 'nın da "Ben de mutluyum çünkü Afganistan'da dedem öldürüldü, eğer orada yaşasaydık başka akrabalarım da öldürülebilirdi, burada eğitim seviyesi yüksek, özgürce yaşayabiliyoruz, okula gidiyoruz o yüzden Türkiye'de yaşamaktan mutluyum.” dediği görülmüştür. Bu bağlamda bu iki öğrencinin söylemlerinin oluşan tüm temaları kapsadığı söylenebilir.

\section{Öğrencilerin Afganistan`a Geri Dönme Konusundaki Görüşleri}

Öğrenciler, Afganistan`a geri dönme hususunda çoğunlukla (Ö1, Ö2, Ö4, Ö5, Ö6, Ö9, Ö10, Ö11, Ö12, Ö13, Ö14, Ö16) geri dönmek istemedikleri, Afganistan` da kötü anıları olması sebebiyle Türkiye`de kalmak istedikleri yönünde görüş belirtmişlerdir. Örneğin Ö1 ek ifadesinde "Hayır dönmek istemiyorum Türkiye daha güzel. Afganistan Türkiye gibi olsa arada sirada ziyaret etmek isteriz." diyerek Türkiye 'yi de vatan olarak benimsediğini ima etmektedir. Yine Ö2 kafa işareti ile arkadaşın tasdik ederek aynı şekilde düşündüğünü belirtmiştir. Sıra ona geldiğinde; "Dönmek istemiyoruz. Çünkü orada amcamın çocuğunun elini kesmişler” diyerek geri dönmeme sebebini orada yaşanan kötü olaylarla ifade etmiştir. Ö9 ise kafa işareti ile arkadaşını tasdik ederek benzer şekilde düşündüğünü beyan etmiştir. Bununla birlikte Ö9`un "Hayır, çünkü orada savaş olur." dediği, Araştırmacı savaş bitse dönmek ister misin diye sorduğunda Ö9; "Hayır" diyerek kalma nedenini sadece savaş ile kayıtlı olmadığını ifade 
etmiştir. Öğrencilerin geri dönmeme sebebini İran`da doğup Afganistan`^ bilmeme nedenine bağlayan Ö6 "Hayır dönmek istemiyorum. Çünkü ben İran'da doğdum. Babam, annem Afganistan'da doğdu. Biz Afganistan'1 bilmiyoruz." şeklinde görüşünü beyan etmiştir. Araştırmacı dönmeme sebeplerinin Afganistan 'da doğmamak olduğunu tespit etmek amaciyla "İran 'da kimler doğdu” diye sorunca Ö2, Ö3 ve Ö4 dışındaki öğrencilerin İran’da doğmadıkları tespit edilmiştir. Ancak Afganistan 'da doğsalar bile bebeklik döneminde Afganistan `da oldukları, dolayısıyla zihinlerinde Afganistan ile ilgili bir çocukluk anılarının olmaması da göz ardı edilmemesi gereken bir husustur. Son olarak Ö16; “Öğretmenim ben elbette ki Türkiye'de yaşamayı seviyorum, fakat doğduğum yerleri, büyüdüğüm yerleri görmek isterim, onun için Afganistan`a gitmek isterim ancak savaş bitse de Türkiye'de yaşamak isterim." diyerek Türkiye' de yaşama isteğinin Afganistan`a vatan olarak bağlılığın önüne geçtiğini göstermiştir.

Afgan uyruklu öğrencilerin az bir kısmı ise (Ö3, Ö7, Ö8) dönmeyi düşündüklerini ifade etmişlerdir. Örneğin Ö3; “Ben Afganistan'a dönmek isterim. Ancak orası da Türkiye gibi savaşsız olursa annem de dönmek istiyor ben de. Ben aslında İran'da doğdum Afganistan'1 görmedim ama görmek istiyorum.” diyerek annesinin de etkisiyle şartların düzelmesi şartıyla dönebileceğini ifade etmiştir.

\section{Öğrenci Çizimlerinde Vatanseverlik}

Araştırmada Türkiye Cumhuriyeti denilince öğrencilerin algılarında oluşan ilk imajı ortaya çıkarmak maksadıyla dağıtılan boş kâğıtlara Türkiye Cumhuriyeti devletinin onlar için ne anlam ifade ettiğini ifade eden bir resim/obje çizmeleri talep edilmiştir. Yapılan bu uygulamadan maksat, öğrencilerin ilk izlenimlerini tespit etmek olduğundan öğrencilere herhangi bir boya vb. malzeme dağıtılmamış, sınırlı zaman içinde karakalem çalışmaları istenmiştir. Uygulama sonunda çizdikleri resimlerde ne anlatmak istedikleri öğrencilere sorularak kayıt altına alınmıştır. Öğrencilerin çizim ve açıklamalarına göre temalar; Güzel Okulum, Türk Bayrağ1 ve Özgür/Güçlü Türkiye şeklinde isimlendirilmiştir.

Öğrencilerin çizimleri incelendiğinde çizimlerin yarıdan 1 fazlası Güzel Okulum alt teması adı altında toplandıkları anlaşılmaktadır. Öğrencilerin çizimlerinde ve yorumlarında; çok sevilen (Ö1), beğenilen (Ö2) adil ve güvenli (Ö3, Ö13), huzurlu (Ö6), okullarını anlatmak istedikleri görülmektedir. Bu temaya ait öğrenci çizim ve görüşleri aşağıdaki gibidir: 
Resim 1: Ö1'e Ait Çizim

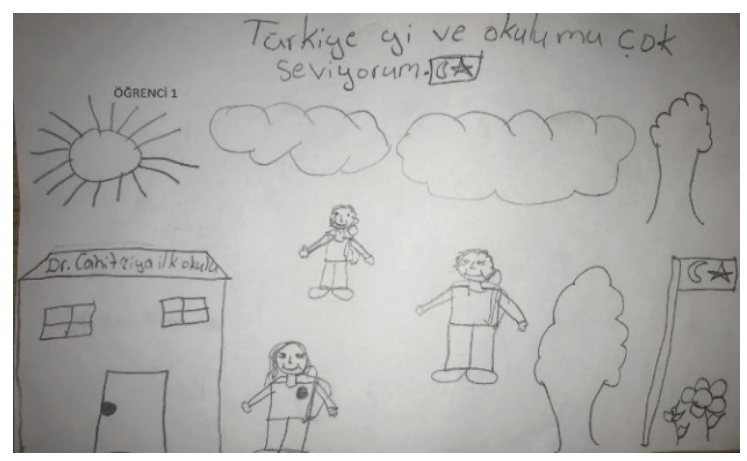

Ö1'in çizimi ile ilgili yorumu: "Okul sevgisini anlatmak için çizdim okulumu seviyorum. Türkiye'de olmaktan, burada okumaktan memnun olduğumu anlatmak istedim."

Resim 2: Ö2'ya Ait Çizim

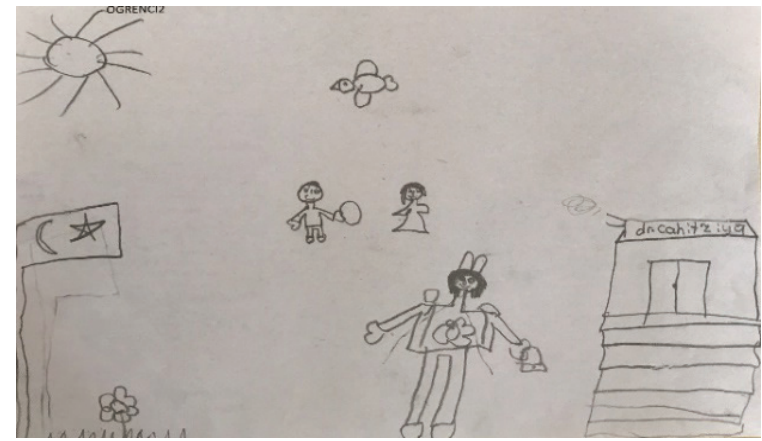

Ö2'nin çizimi ile ilgili yorumu: "Türkiye güzel olduğunu okulun güzel olduğunu burada yaşamanın güzel olduğunu anlatmak için Türk bayrağını Okulu ve arkadaşlarımı çizdim."

Resim 3: Ö3'e Ait Çizim

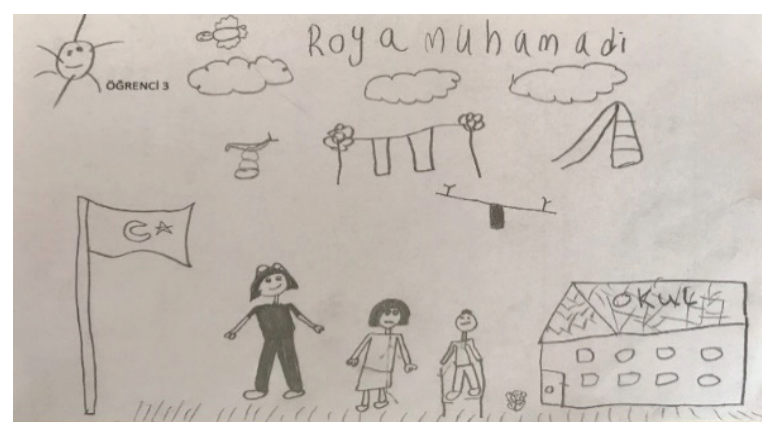

Ö3'ün çizimi ile ilgili yorumu: "Öğretmenimi, okulumu, arkadaşlarımı çizdim, öğretmenimizle pikniğe gidiyoruz gibi çizdim. Ben okulumu seviyorum ve mutluyum." 
Resim 4: Ö4'e Ait Çizim

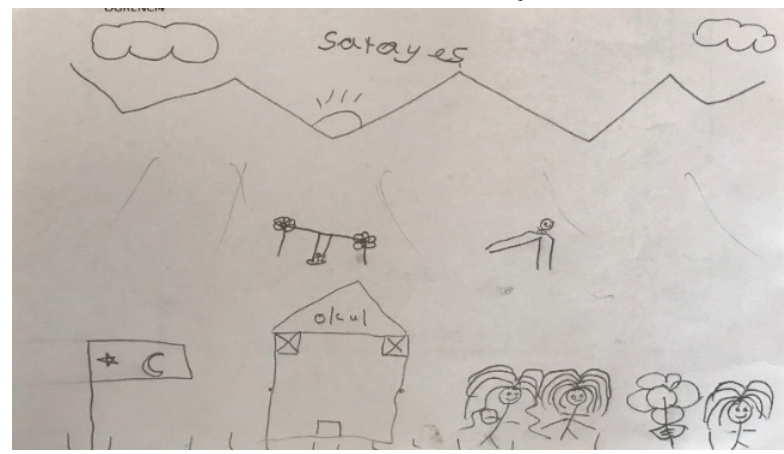

Ö4'ün çizimi ile ilgili yorumu: "Arkadaşlarımla okulda oyun oynadığımı anlatmak istedim, okulumu sevdiğimi ve mutlu olduğumu ifade etmek istedim."

Resim 5: Ö6’ya Ait Çizim

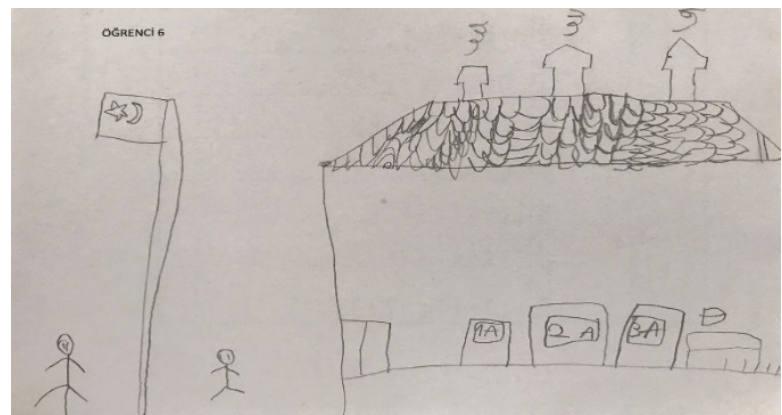

Ö6'nın çizimi ile ilgili yorumu: "Okulumu ve arkadaşlarımla birlikte sınıfımı çizdim, memnun olduğumu anlatmak istedim."

Resim 6: Ö7’ye Ait Çizim

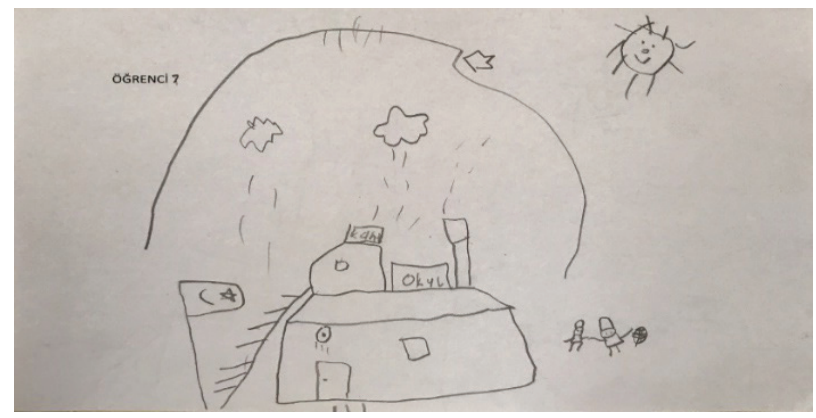

Ö7"nin çizimi ile ilgili yorumu: "Okulu, park1 çizdim burada yaşamın rahat olduğunu ve mutlu olduğumu anlatmak için çizdim." 


\section{Resim 7: Ö9’a Ait Çizim}

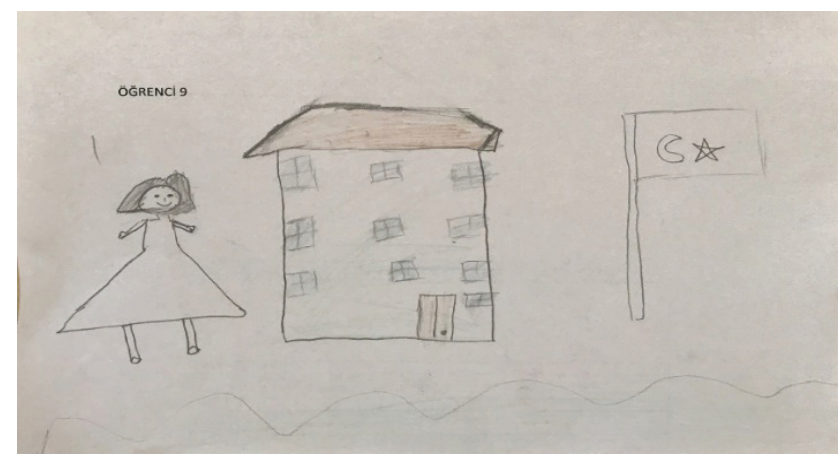

Ö9'un çizimi ile ilgili yorumu: "Okul ve bayrak çizdim. Çünkü Türkiye»de okumak istediğim için."

Resim 8: Ö13’e Ait Çizim

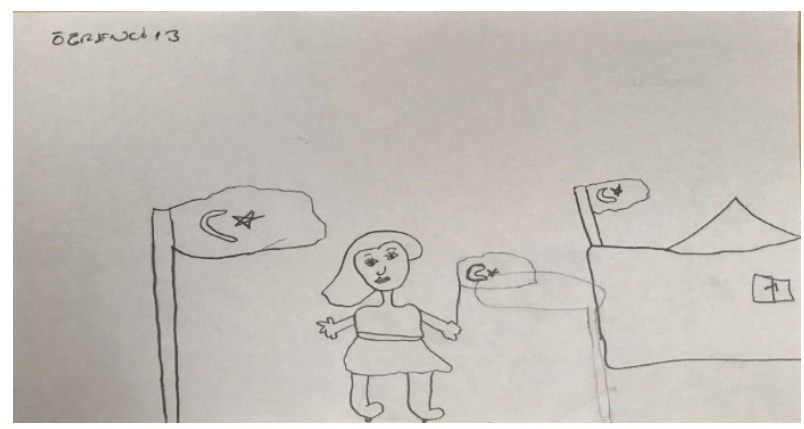

Ö13'ün çizimi ile ilgili yorumu: "Okulumu ve arkadaşlarımı çizdim."

\section{Resim 9: Ö15’e Ait Çizim}

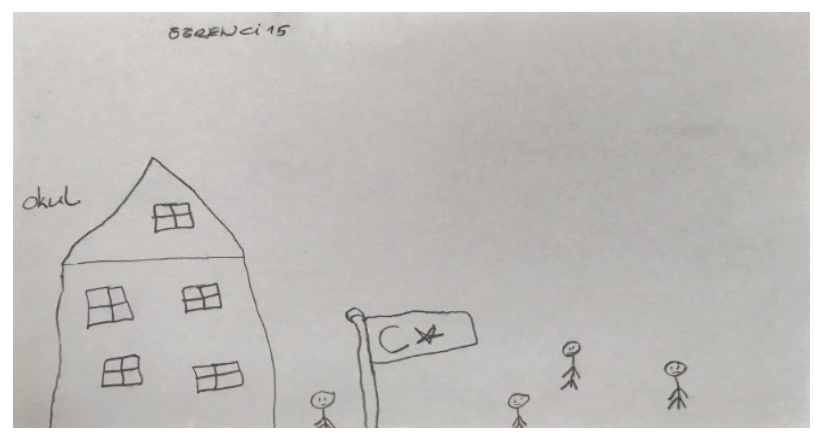

Ö15'in çizimi ile ilgili yorumu: "Okul, bayrak ve çocukları çizdim, okulumu sevdiğimi ifade etmek için." 
Güzel Okulum alt temasının ardından altı öğrencinin çizimi de Türk Bayrağ alt teması altında toplanmıştır. Bu temaya giren öğrencilerin çizimlerinde ve çizimlerini açıkladıkları ifadelerinde Türk insanının yardımseverliğini (Ö8, Ö10, Ö11, Ö12, Ö14, Ö16) anlattıkları çizimler ön plana çıkmaktadır. Bu temaya ait öğrenci çizim ve görüşleri aşağıdaki gibidir:

Resim 10: Ö8’e Ait Çizim

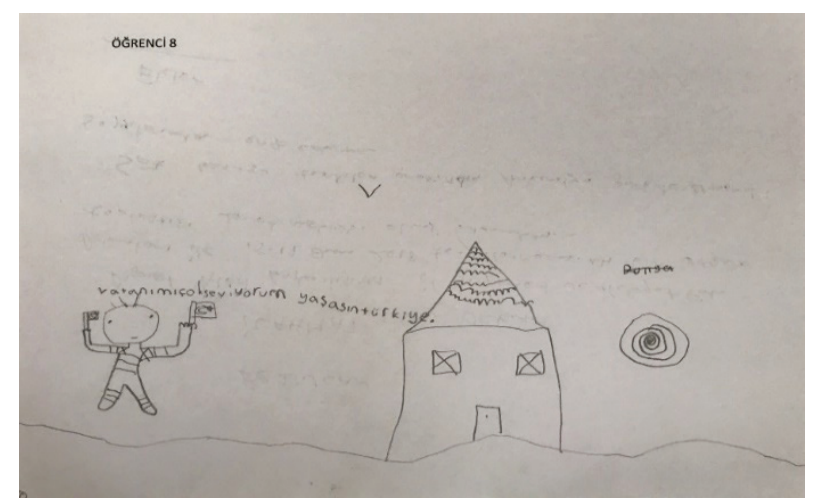

Ö8'in çizimi ile ilgili yorumu: "Evde çocuk çizdim, mutlu olduğunu, elinde Türk bayrağı ile gösterdim." Araştırmacı; "Vatanımı çok seviyorum derken Türkiye yi mi kastettin?" diye sordu. O da "evet" dedi.

Resim 11: Ö10’a Ait Çizim

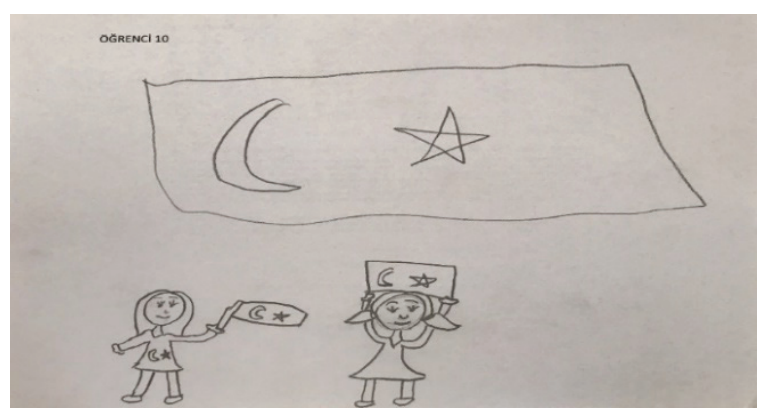

Ö10'ün çizimi ile ilgili yorumu: "Elinde Türk bayrağı olan ben ve arkadaşımı çizdim." 
Resim 12: Ö11'a Ait Çizim

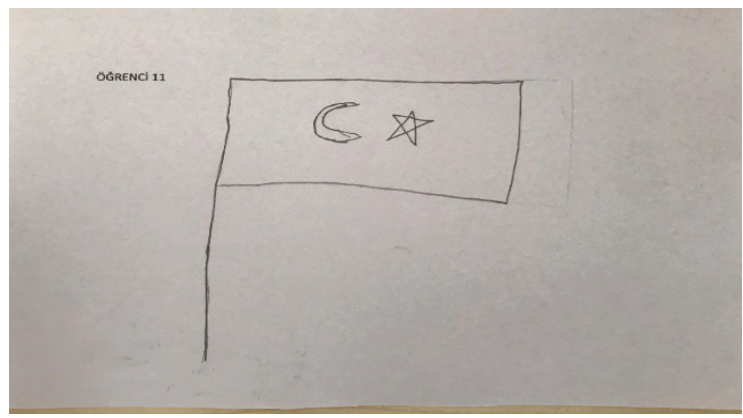

Ö11'in çizimi ile ilgili yorumu: "Bayrak çizdim, Türkiye deyince Türk bayrağ1 aklıma geliyor."

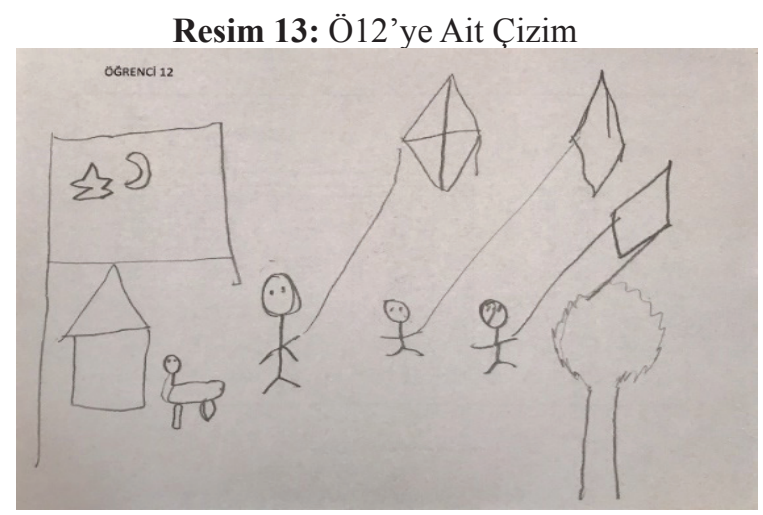

Ö12’nin çizimi ile ilgili yorumu "Bayrak çizdim, uçurtma uçuran çocuklar çizdim. Türkiye>de mutlu olduğumu ifade etmek için."

Resim 14: Ö14`e Ait Çizim

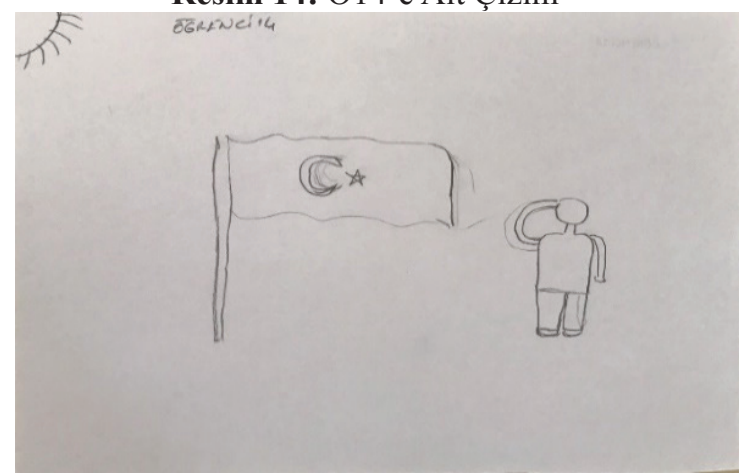

Ö14'ün çizimi ile ilgili yorumu: "Bayrak ve Ona selam duran kendimi çizdim." 


\section{Resim 15: Ö16 ya Ait Çizim}

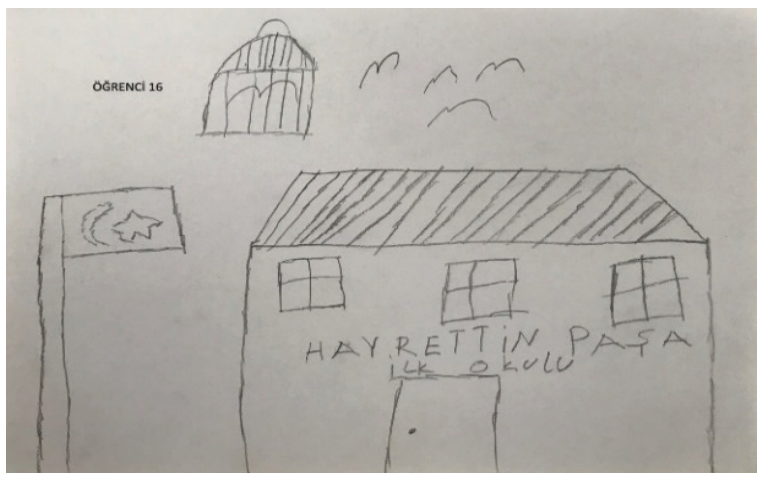

Ö14'ün çizimi ile ilgili yorumu: "Türkiye bayrağını çizdim. Çünkü her bayrak o Bir ülkeyi temsil eder ve o ülkenin özgürlüğü ve bağımsızlığını ifade eder Türkiye'de özgür bir ülke olduğu için bayrağını çizdim kafeste bir kuş ve uçan kuşlar çizdim Kimse kimsenin özgürlüğüne engelleyemez anlamında. Okulumuzu çizdim, çünkü okulumuzda çok iyi insanlar var.”

Türk Bayrağı temasından sonra bir öğrencinin çiziminde odaklandığ 1 bir diğer tema da Özgür/Güçlü Türkiye`dir. Ö5 çiziminde Türkiye'ye karşı yapılan saldırıları resmetmiştir. Ö5`e ait çizim ve görüş aşă̆ıdaki gibidir:

\section{Resim 16: Ö5'e Ait Çizim}

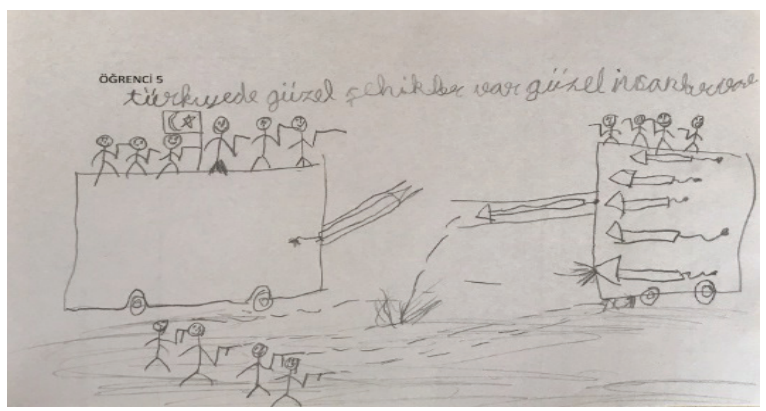

Ö5'in çizimi ile ilgili yorumu: "Türkiye'ye düşmanların saldırdığını anlatmak istedim." Araştırmacı "Sen de savaşır mısın?" diye sorunca gülerek "Ben küçügüm, büyüyünce savaşırım.” dedi.

\section{Öğrencilerin İstiklal Marşı Hususundaki Görüşleri}

Öğrencilere İstiklal Marşını bilip bilmedikleri sorulmuş, biliyorlarsa ezbere okumaları istenmiş öğrencilerin tamamı İstiklal Marşını az bildiklerini ve 1-2 kıtasını okuyabileceklerini belirtmişlerdir. Görüşme grubundaki öğrencilerin 
çoğunluğu 2. ve 3. sınıfta olmaları ve eğitim seviyeleri dikkate alındığında; Türk milletinin millî değerlerinden olan İstiklâl Marşını ve ulusal söylemlerini öğrenmeye başladıkları, ezberledikleri kısımları okuyabilecek seviye de bildikleri görülmüştür.

\section{Öğrencilerin Tariflerinde Vatanseverlik}

Araştırma kapsamında öğrencilerden vatanseverliği tarif etmeleri istenmiştir. Öğrencilerin yaptıkları tariflere bakıldığında tüm görüşlerin vatan için şehit olmak, vatan için görevini yapmak, Türkiye yi sevmek şeklinde üç alt temada toplanmıştır. Her bir öğrencinin yaptığ 1 tarif, Şekil 2'de ayrıntılı olarak gösterilmektedir:

Şekil 2: Afgan Öğrencilerinin Vatanseverlik Tarifleri

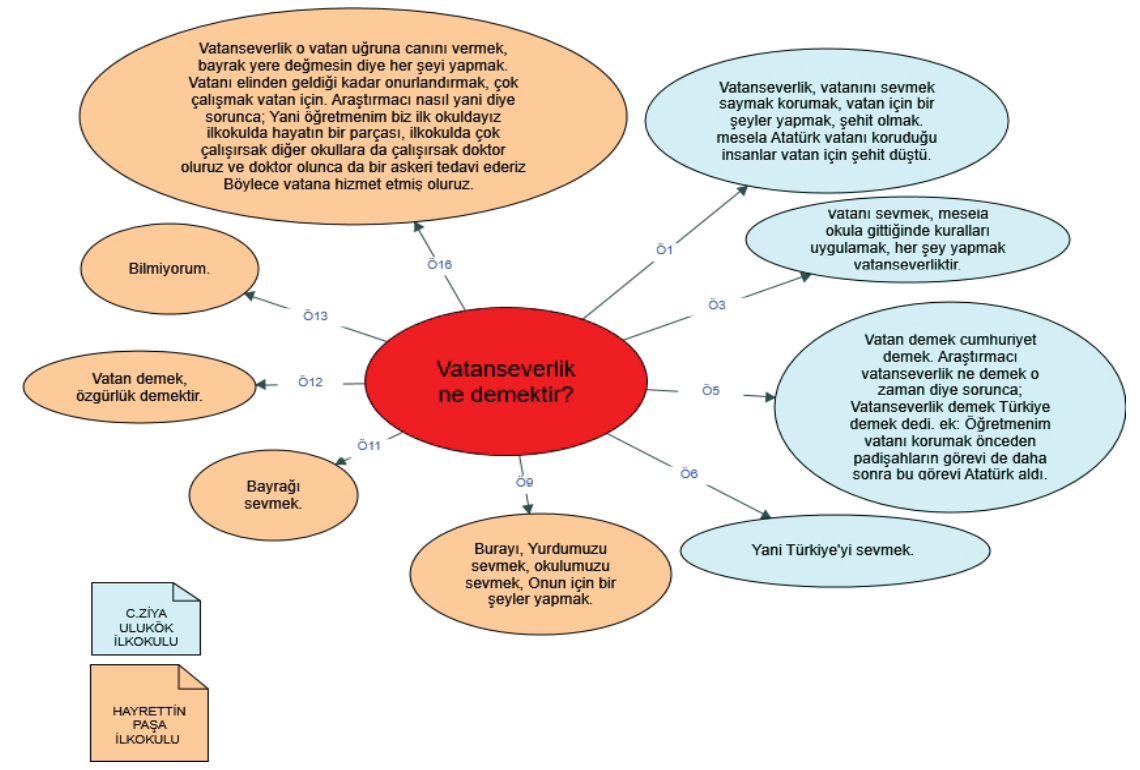

Vatan için şehit olmak alt temasına ilişkin öğrenci görüşleri incelendiğinde Ö1; "Vatanseverlik vatanını sevmek, saymak, korumak, vatan için bir şeyler yapmak, şehit olmak, mesela Atatürk vatanı korudu, insanlar vatan için şehit düştü." diyerek vatanı sevmeyi, uğruna şehit olmakla kutsallaştırarak ifade ederken Ö16 cevabının bir kısmında "Vatanseverlik o vatan uğruna canını vermek, bayrak yere değmesin diye her şeyi yapmak..." diyerek Ö1 ile benzer şekilde görüş ifade etmiştir. 
Vatan için görevini yapmak alt temasına ilişkin öğrenci görüşleri incelendiğinde Ö16 cevabının diğer bölümünde "Vatanı elinden geldiği kadar onurlandırmak, çok çalışmak vatan için. Araştırmacı "Nasıl yani?" diye sorunca; yani öğretmenim biz ilk okuldayız, ilkokulda hayatın bir parçası ilkokulda çok çalışırsak diğer okullara da çalışırsak (ilkokuldan sonraki eğitim dönemlerini kastediyor) doktor oluruz ve doktor olunca da bir askeri tedavi ederiz. Böylece vatana hizmet etmiş oluruz." diyerek vatanseverliğin farklı bir boyutu olan görev bilinci ile tarif ederken öğrencilerin bir kısmı aynı anlama gelen "okulda kurallara uymak" (Ö3), "Onun için (Vatan`1 kastediyor.) bir şeyler yapmak" (Ö9) şeklinde görüş belirtmişlerdir. Bununla birlikte öğrencilerin cevaplarında Atatürk vurgusu dikkat çekicidir. Örneğin, Ö1; “...Mesela Atatürk vatanı korudu..." şeklinde ifadesiyle Atatürk ü diğer Türk öğrenciler gibi benimsediği, Ö5' in ise benzer şekilde "Öğretmenim vatanı korumak önceden padişahların göreviydi. Daha sonra bu görevi Atatürk aldı." diyerek Osmanlı ile Atatürk arasında bağ kurarak bu durumu ifade ettiği görülmüsştür. Bu durum okulda verilen eğitimin öğrenciler üzerinde olumlu etkileri olarak yorumlanabilir.

Türkiye yi sevmek, alt temasına ilişkin öğrenci görüşleri incelendiğinde Ö6 "Yani Türkiye'yi sevmek." diyerek vatanseverliği Vatanı kabul ettiği Türkiye yi sevmek ile özdeşleştirmiş, benzer şekilde Ö5` de vatanseverliği Türkiye sevgisiyle açıklamıştır. Bununla birlikte Ö9 "Burayı, yurdumuzu sevmek" diyerek aynı hususa vurgu yaparken Ö11 ise "Bayrağı sevmek" şeklinde ifade etmiştir. Öğrenci ifadelerinden Türkiye`yi vatan olarak benimsedikleri açıkça anlaş1maktadir.

$\mathrm{Bu}$ temada bazı öğrencilerin tarif yapamadıkları için cevap vermedikleri görülmüş, Ö13 ün ise daha açık bir şekilde "Bilmiyorum." diyerek bu durumu ifade ettiği görülmüştür.

\section{Tartışma ve Sonuç}

Vatanseverlik, yaşadığı toprak ve bu toprağın üstünde aynı bayrak altında yaşayanları bir arada tutan ve içinde bulunulan iç ve dış konjonktürün etkisinde şekillenen önemli bir kimliktir. İlkokulda okuyan Afgan uyruklu mülteci öğrencilerin vatanseverlik algılarını ele alan bu araştırma, gerek Afganistan`dan Türkiye'ye uzanan göç süreci, gerekse Türkiye'ye yerleştikten sonra almaya başladıkları örgün eğitim ve yaşadıkları sosyal hayatın üzerlerinde bıraktığı etkilerini açık bir şekilde ortaya koymaktadır. 
Afganistan uyruklu öğrencilerin Türkiye de kalma süreleri incelendiğinde çoğunluğun 5 yıl ve üzerinde ikamet ettikleri bu sürenin topluma entegre olma, dil öğrenme ve sorulan sorulara cevap vermeleri için yeterli bir zaman aralığıdır. Ancak öğrenci ifadelerinde yer bulan Türkiye Cumhuriyeti devletinin onlara kucak açması, yardım etmesi, Türkiye de yaşam olanaklarının daha rahat ve konforlu olması yanında onların da Türkiye'yi ve Türk vatandaşlarını sevmelerinin etkisi de göz ardı edilmemelidir. Nitekim Türkiye'ye gelmeden önce -bazı öğrencilerin ifade ettikleri gibi- İran’da barınma, iş bulma, eğitim gibi hususlarda sıkıntı yaşamaları sebebiyle Türkiye'ye göç etmeleri bu savımızı desteklemektedir.

Öğrencilerin Türkiye ye göç etme sebeplerinin başında Afganistan 'daki iç savaş sebebiyle olduğu, bunun yanında iyi eğitim alma isteğinin de etkili olduğu söylemlerinden anlaşılmaktadır. Ayrıca -2 öğrencinin ifadelerinde dile getirdikleri- Afganistan`da eğitim imkanlarının sunumunda kız öğrencilere yönelik cinsiyet eşitsizliğinin etkili olduğu, bazı ailelerin İran ’da kalmayıp Türkiye ye göç etme sebeplerinden birinin de eğitim hizmetlerinin sunumunda kızlara negatif ayrımcılık yapılmasının olduğu görülmektedir. Ayrıca bazı öğrencilerin bu durumu din eğitimiyle bağdaştırarak kız öğrencilere yapılan negatif ayrımcıl1ğın dini eğitim sebebiyle olduğunu, kız öğrencilere eğitim olanağı sunulmasını medeni eğitim olarak açıklamaları dikkat çekicidir. Elde edilen bu bulgu, Boyraz (2015) ve Şahin, Bakal ve Balçın (2018) `ın bulgularıyla uyumludur. Zira, Suriyelilerin ülkelerinden ayrılma nedenlerinin başında, savaş sebebiyle maruz kaldıkları can güvenliği ve eğitim sorunudur.

Öğrenciler Türkiye’de yaşamaktan dolayı kendilerini mutlu, huzurlu ve güven içinde hissetmektedirler. Öğrencilerin Türkiye'ye göç etme nedenleri arasında saydıkları iyi insanların olması, ayrım yapılmaması, daha iyi eğitim almaları, Türkiye 'de savaş olmaması gibi söylemleri bu savı desteklemektedir. Bu bağlamda öğrencilerin eğitim gördükleri okullarda okul yönetiminden ve öğretmenlerinden gördükleri muamele, sınıf arkadaşlarıyla ilişkileri, Türk halkının misafirperverliği, Türkiye Cumhuriyeti’nin mazlum halklara karşı gösterdiği kadirşinas tavrı ile açıklanabilir. Bunun yanında Afgan mülteciler ile Türk halkı arasındaki toplumsal değerler, kültürel ve dinî yakınlığında etkisi yadsınamaz bir gerçektir. Bu durum Tosun, Yorulmaz, Tekin ve Yıldız (2018)'ın ulaştıkları bulgular ile Şahin vd. (2018)'nin yabancı uyruklu öğrencilerden Müslüman olanların, Eskişehir'de dinî yönden yabancılık çekmedikleri bulgularılla kısmen uyumludur. Ayrıca Palaz, Çepni ve Kılcan (2019)'ın yaptıkları “Ortaokul 
Öğrencilerinin Mülteci Öğrencilere Yönelik Düşüncelerinin ve Tutumlarının Belirlenmesi" adlı araştırmada; yerli öğrencilerin büyük bir bölümünün mültecilerin Türkiye'ye gelmesini olumlu karşıladıkları, bazı öğrencilerin ise mültecilerin Türkiye'de bulunmasından hoşnut olmadıkları sonucuna ulaşmışlardır. Bu sonuç, araştırma sonuçlarını büyük oranda destekler niteliktedir. Ayrıca Millî Eğitim Bakanlığı ikinci Sınıf Hayat Bilgisi kitaplarında yer alan "Farklı Kültürler” başlığı altında Türkiye ye göç eden insanlara karşı saygıllı ve hoşgörülü olunması hususundaki kazanımların da etkisini yadsımamak gerekir (Bkz. Ulusoy, t.y., s.175-176)

Afganistan`a geri dönme hususunda öğrencilerin çoğu Afganistan`da yaşadıkları kötü anıları olması ve Türkiye 'nin huzurlu, güvenli bir ülke olması sebebiyle geri dönmeyi düşünmemektedir. Hatta Afganistan`da savaş bitse dahi dönmeyi düşünmediklerini, ziyarete-görmeye gidebileceklerini ifade etmişlerdir. Bu bağlamda öğrencilerin öz vatanlarıyla olan bağlarının kesilmeye yüz tuttuğunu, öz vatan olarak Türkiye'yi benimsedikleri şeklinde yorumlanabilir. Öğrencilerin çoğunun Afganistan`da doğmamaları (Öğrencilerin neredeyse tamamı İran doğumludur.), Afganistan`a ait hatıralarında çocukluk anılarının olmaması bu sonuca götüren etkenlerdendir.

Öğrencilerin kafalarında oluşan Türkiye hakkındaki düşüncelerini çizdikleri ve kendi ifadeleriyle açıkladıkları çizimleri; Güzel Okulum, Türk Bayrağı ve Özgür/Güçlü Türkiye adlı 3 tema da toplanmıştır. Öğrencilerin çoğunun Türkiye yi yaşanabilir, emniyetli güzel bir ülke olarak çizmeleri ve bunu okuldaki memnuniyet üzerinden ifade etmeleri, ilk ve en çok sosyalleştikleri alan olarak okuldan, öğretmenlerinden, arkadaşlarından gördükleri iyi muamele sebebiyle olduğu düşünülmektedir. Zira okulda mutlu olma nedenleri arasında emniyet ve güven içinde huzurlu bir şekilde eğitim hayatlarını ve diğer sosyal yaşamlarını sürdürmelerinin önemli etkenlerden biri olduğunu söylemlerinde ifade etmişlerdir. Bununla birlikte Türk bayrağını çizimlerinde yoğun olarak kullanmaları, ifade edecekleri temayı bayrak imgesiyle resmetmeleri, Türkiye'ye saygı ve güveni ifade etmekle birlikte Türkiye 'yi kendileri için vatan olarak algıladıklarının ve Türk bayrağını bir değer olarak benimsediklerinin göstergesidir. Ayrıca bir öğrencinin Türkiye yi düşmanlarıyla savaşan bir ülke olarak ifade etmesi, kendisinin de büyüyünce savaşabileceğini ifade etmesi vatan aidiyetinin oluştuğunun diğer bir göstergesi olarak sunulabilir.

Öğrencilerin İstiklal Marşının bilinmesi konusunda görüşme grubundaki öğrencilerin ilkokul ikinci sınıfta okudukları dikkate alınınca 1-2 kıtasını oku- 
yabildiklerini ifade etmeleri, Türk millî değerlerini benimsemeye başladıkları şeklinde yorumlanabilir.

Öğrencilerin vatanseverlik tarifleri arasında en çok vatan uğruna şehit olmak vurgusu dikkat çekmektedir. Bu anlamda öğrencilerin kendi değer sıralamalarında vatanseverlik değerini üst noktada bir yere konumlandırdıkları anlaşılmaktadır. Araştırma sonuçları, Özensel (2004) Gömleksiz ve Cüro (2011) ve Elban``n (2015) öğrencilerin vatanseverlik değerine karşı olumlu tutum düzeylerinin yüksek olduğu bulgusuyla uyuşmaktadır. Öğrencilerin tariflerinde vatan için ölmenin yanında, vatan için görevini en iyi şekilde yapmayı, bireysel-toplumsal fayda üretmeyi vatanseverliğin bir parçası olarak görmeleri önemlidir. Ayrıca vatan için çalışmayı Atatürk örneği üzerinden açıklamaları ve bunu Osmanlı devleti ile bağ kurarak açıklamaları Türkiye 'de aldıkları eğitimin olumlu etkisi olarak görülebilir.

Göksu ve Kayalar (2018) tarafından yapılan ortaöğretim öğrencileri üzerinde yapılan benzer araştırmada öğrencilerin çizim ve açıklamaları; Güzel Türkiye, Yardımsever Türkiye ve Müslüman Türkiye şeklinde üç alt temada toplanırken, vatanseverlik tarifleri ise vatan için savaşmak/ölmek, vatana hizmet etmek, vatandaşlara sahip çıkmak, vatan için okumak şeklinde dört alt temada toplanmıştır. Araştırma sonuçlarına göre Afganlı Öğrencilerin öz vatanlarına karş1 sevgilerinin devam ettiği, mücbir sebeplerle Türkiye'ye göç etmek zorunda kaldıklar1, Türkiye' de kendilerine sunulan yardım vb. imkanlar ve Türk vatandaşlarının kucak açması sebebiyle mutlu oldukları, Türkiye ye karşı ve Türk halkına karşı olumlu duygular besledikleri görülmüştür. Her iki araştırma sonucu arasında benzerlikler olmakla birlikte yaş farkı, Afganistan doğumlu olmak ve oraya ait yaşanmış acı/tatlı hatıralardan kaynaklı farklılıklarda ortaya çıktı̆̆ görülmüştür.

Sonuç olarak Afganlı göçmeni öğrencilerin öz vatanlarına karşı sevgilerinin, Afganistan doğumlu olmamaları sebebiyle Afganistan`a ait yaşanmış bir anıları olmamasından mülhem kaybolmaya başladığı, zorunlu sebeplerle Türkiye ye göç ettikleri, Türkiye'de kendilerine sağlanan iyi eğitim, rahat yaşam, yardım vb. imkânlar ile okuldaki öğretmen ve arkadaşlarının onlara karşı olumlu tutumları sebebiyle mutlu ve huzurlu oldukları, Türk halkına ve Türkiye 'ye karşı ziyadesiyle olumlu duygular besledikleri, öğrencilerinin büyük çoğunun Türkiye yi ana vatan olarak benimsemeye başladıkları araştırma sonucunda ulaşılan en önemli bulgularındandır. 


\section{Kaynakça}

Adıgüzel, Y. (2016) Bir toplumsal değişim katalizörü olarak göç olgusu, Berkehan Kıran (Ed.), Toplumsal Değişim Sempozyumu İçinde, 483-492.

Akıncı, B., Nergiz, A., \& Gedik, E. (2015). Uyum süreci üzerine değerlendirme göç ve toplumsal kabul. Göç Araştırmaları Dergisi, 1(2), 58-83.

Balc1, M. (2014). Değerleri yaşatmak ve değerler sözlüğü (1. Baskı). İstanbul: Ensar Neşriyat.

Bates, C. D. (2002) Environmental refuugee? Classifying human migration caused by environmental change. Population and Environment, 23, (5), 465-477.

Berg, B.L. ve Lune, H. (2015). Sosyal bilimlerde nitel araştırma yöntemleri. (Ed. H. Aydın Çev.). Konya: Eğitim Yayınevi.

Black, R. (2014) Refugees, Evironment and development. Newyork: Routlage.

Bolay, S.H. (2013). Aşkın değerler buhranı, R. Kaymakcan, S. Kenan, H. Hökelekli, Ş. Arslan, M. Zengin (Ed.), Değerler ve Eğitimi Uluslararası Sempozyumu İçinde (ss.55-70). İstanbul: Dem Yayınları.

Boyraz, Z. (2015). Türkiye'de göçmen sorununa örnek Suriyeli mülteciler. Journal Of World Turks. 7(2).

Börü, N. Boyacı, A. (2016). Göçmen Öğrencilerin eğitim-öğretim ortamlarında karşılaştıkları sorunlar: Eskişehir İli örneği. International Periodical for the Languages, Literature and History of Turkish or Turkic Volume 11(14), 123-158.

Crick, E.R. (2012). Farklı kavramlar mı, madalyonun iki değişik yüzü mü? Değerler Eğitimi Uluslararası Konferansı İçinde (ss.196-202). Damla Yayınevi.

Creswell, J.W. (2013). Nitel araştırma yöntemleri. (M. Bütün \& S.B. Demir, Çev. Edit.), Ankara: Siyasal Kitabevi.

Elban, M. (2015) “Ortaöğretim öğrencilerinin vatanseverlik tutumları: Ankara İli Kazan ilçesi örneği”. The Journal of Academic Social Science Studies. 35, 451-462.

Ergen, G. (2006). Eleştirel-bilinçli sevgi eğitimi. Burdur Eğitim Fakültesi Dergisi. 8(12), 144-152.

Glesne, C. (2013). Nitel araştırmaya giriş. (Ed. A. Ersoy ve P. Yalçınoğlu Çev.). Ankara: Anı Yayıncılık.

Göksu, M. Z., \& Kayalar, F. (2018). Value of patriotism in the perspective of afghan students attending to secondary schools. Journal of Social \& Humanities Sciences Research, 29, 3806-3817. 
Gömleksiz, M. N., Cüro, E. (2011). Sosyal Bilgiler dersinde yer alan değerlere ilişkin öğrenci tutumlarının değerlendirilmesi. Uluslararası İnsan Bilimleri Dergisi. 8(1), 95-134.

Güngör, E. (1997). Ahlak psikolojisi ve sosyal ahlak (2.Bask1). İstanbul: Ötüken Neşriyat.

Hanson, M. (2018), The origin story of migrant rights, Wall Street International, Erişim adresş: https://wsimag.com/economy-and-politics/45053-the-origin-story-of-migrant-rights

......(T.y.) Erişim adresi: https://www.bbc.com/turkce/haberler-turkiye-43668567.

.....(T.y.) Erişim adresi: https://www.goc.gov.tr/kurumlar/goc.gov.tr/Istatistikler/ AGUSTOS/19AGUSTOS/18_Yillara_gore_yakalanan_duzensiz_gocmenlerin_uyruk_dagilimi_03_07_2019.jpg.

Göç. (T.y.) Erişim adresi: https://sozluk.gov.tr/

Huddy L.ve Khatip N. (2010). American patriotism, national 1dentity, and political involvement, American Journal of Political Science, 51(1), 63-77.

Jenner, C. (2015) Breaking the cycle:Education and the future for Afghan refugees. Erişim adresi: https://Www.Unhcr.Org/Nansen/Breaking_The_Cycle_Report_2015.Pdf.

Kandemir, F. (2019). Umut, iyimserlik ve dindarlık (1. Bask1). Erzincan: Doğu.

Kaymakcan R. (2012). Gençlerin dini değerlere bakışı türkiye ve avrupa karşılaştırması. Değerler Eğitimi Uluslararası Konferans Bildirileri (Mayıs 2010) İçinde (s.13-30). İstanbul: Damla Yayınevi.

Kirschenbaum, H. (1995). 100 ways to enhance values and morality in school and youth settings. USA: Allyn and Bacon.

Merriam, S. B. (2013). Nitel araştırma desen uygulama için bir rehber. (S.Turan, Çev. Edit.), Ankara: Nobel.

Nazıroğlu, B. (2013). Vatandaşlık ve din eğitimi. İstanbul: Açılım Kitap.

Özensel, E. (2004). Liseli kız ve erkek öğrencilerin değer yargıları ve türk toplumunun temel toplumsal kurumlarına bakış açıları, R. Kaymakcan, S. Kenan, H. Hökelekli, Ş. Arslan, M. Zengin (Ed.), Değerler ve Eğitimi Uluslararası Sempozyumu İçinde (ss.743-769). İstanbul: Dem Yayınları.

Palaz, T., Çepni, O., \& Kılcan, B. (2019). Ortaokul öğrencilerinin mülteci öğrencilere yönelik düşüncelerinin ve tutumlarının belirlenmesi. Turkish Studies, 14(3), 1661-1684.

Patton, M.Q. (2014). Nitel araştırma ve değerlendirme yöntemleri (Çev. M. Bütün, S.B. Demir), Ankara: Pegem Akademi.

Rokeach, M. (1973). The nature of human values. (4th ed.). Newyork: The Free 
Press.

Şahin, M. Bakal S. Balçın, Ö. (2018). Afgan mültecilerin Türk kültürüne uyum süreçlerine ilişkin görüşleri. 4. Uluslararası Çağdaş Eğitim Araştırmaları Kongresi Tam Metin Bildiri Kitabı. Eğitim, Gençlik ve Gelecek içinde (s. 778-787) Muğla: Muğla Sıtkı Koçman Üniversitesi Yayınları.

T.D.K. (2019). Erişim adressi: www.tdk.gov.tr/index.php?option=com_gts\&arama=gts\&guid=TDK. GTS.59fb3ddf6face4.19674211.

Tosun, A., Yorulmaz A., Tekin İ., Yıldız K. (2018). Mülteci öğrencilerin eğitim sorunları, eğitim ve din eğitiminden beklentileri: Eskişehir örneği. Eskişehir Osmangazi Üniversitesi Sosyal Bilimler Dergisi, 2018, 19(1), 107-133.

Uluçevik, T. (2013). Ne mutlu türküm diyene (03 Nisan 2013). Erişim adresi: http:// www.cumhuriyet.com.tr/haber/ne-mutlu-turkum-diyene413322

Ulusoy, Y. (T.Y.). Illkokul hayat bilgisi ders kitabı 2. sınıf. Ankara: Beşgen Yayıncrlik.

Yazıc1, M. (2013). Toplumsal değişim ve sosyal değerler. Turkish Studies, 8, 14891501.

Yıldırım, A. ve Şimşek, H. (2013). Sosyal bilimlerde nitel araştırma yöntemleri. (9. Baskı). Ankara: Seçkin Yayıncılık.

Zabunoğlu, H. G. (2018). Günümüzde ulus devlet. Eskişehir üniversitesi hukukfakültesi dergisi, XIII(1), 535-559. 
Extended Abstract

\section{Patriotism Through the Eyes of Afghan Primary School Students in Turkey}

Mehmet Zeki GÖKSU, Corresponding Author, Assistant Professor. Erzincan Binali Ylldırım University, Faculty of Theology, Turkey. zeki.goksu@erzincan.edu.tr http://orcid.org/0000-0003-0875-2226

Article Type: Research Article https://doi.org/10.34234/ded.598196

Received Date: 29.07 .2019

Accepted Date: 01.05 .2020

Published Date: 25.06 .2020

\section{Introduction}

Value is described as useful, expressive, wise and necessary behaviours and attitudes (Balc1, 2014). Values are the basic policies that guide behaviours (Crick, 2012). It is a powerful belief system that puts an end to personal and socially preferred behavior or creates a special state of mind (Rokeach, 1973: 5). Behaviors are shaped by values. The person develops his/her behavior according to the values he/she has (Kaymakcan, 2012: 13).

Immigration itself and the effects of globalization on the world labour market have become a major political issue. Some immigrants have to flee from their country because of civil war, crop failure, job shortages, natural disasters whereas others decide to leave due to low quality of life or education and health system along with the poor living conditions. The prevalence of various problems is influenced by the nature of immigration amongst those who have to flee their country to find themselves new lands to settle in and start building a new life. 
Whether migration is voluntary or compulsory, it should be considered not only a physical and geographical displacement, but a phenomenon that encompasses the whole life and reconstructs human-space relations for the immigrant and host communities (Adigüzel 2016: 483). Refugees problem is also reflected in the "Breaking the Cycle: Education and the Future for Afghan Refugees" a report prepared by Jenner (2015: 3-6) for the United Nations High Commissioner for Refugees and the Norwegian Refugee Council, it says that; After the fall of the Taliban regime in 2001, there has been a substantial increase in education, but still 3,500.000 children are unable to go to school and there are still obstacles - especially for girls - cultural pressures, poor quality education opportunities, etc. Afghan refugees children, who mostly fled to Iran and Pakistan, face serious difficulties even if they are admitted to local schools.

The aim of this study is to investigate the patriotic understanding of Afghan refugee children residing in Erzincan city center that are given the opportunity to access primary education and to discover their perception of patriotism towards their homeland and their host country.

\section{Methods}

\section{Research Design}

In the studies which aim to determine the patriotic consciousness of Afghan refugee primary school students, and to identify their national identification and national consciousness towards Turkey. The research is a case study from qualitative research methods and a focus group interview method is used, which is considered as one of the qualitative research methods.

\section{Study Group}

The population of the study consists of Afghan refugee students studying at Cahit Ziya Ulukok Primary School and Hayrettinpasa Primary School in Erzincan province 2018-2019 academic year. The study group consists of 16 students in total selected among these students with a purposeful sampling strategy.

\section{Data Collection Tool}

As a data collection tool, semi-structured interview form consisting of six open-ended questions was used by the researchers. In addition, in order to ex- 
press the views of the participant students in different ways, they were asked to paint the visual embodiment of patriotism on the papers given to them during the interview; these documents were collected after the interview to be used in the research.

\section{Data Collection Process}

The data were collected from the focus group interviews via camera recordings by the researcher in both schools. The participants were informed both about the aim of the research and the general rules of the focus group interview before the application. In this context, it was emphasized that the data would be obtained on a voluntary basis, evaluated by names, the images would not be published in any way and they would not be shared with third parties, the answers given by the participants would not be judged as true or false, and the participants were asked to answers the questions sincerely and heartily. After the interviews were completed, one more copy of camera records for transcription and analysis were kept in substitution.

\section{Analysis of the Data}

The data obtained by transcribing the camera recordings were analysed using the qualitative method research program NVIVO 11 PLUS. Descriptive analysis method was used in the analysis of interviews. As a necessity of this method, the data are summarized and interpreted according to the predetermined themes (Yıldırım and Şimşek, 2013). In order to increase the quality of the report, descriptive findings and analyses were tried to be presented in a brief and concise way (Patton, 2014).

\section{Validity and Reliability}

Necessary measures have been taken to ensure validity in the research. In this context, in the preparation of the questions of the semi-structured interview form which is used as data collection tool, it was sent to seven educational research experts, then necessary corrections were made in the light of the feedback. During the preparation, the interview form and the list of questions were put as open-ended, without orientation but with simplicity to be understood by the participants. Under the expert opinions, the interview form and the list of questions were tested with five students selected from the schools to be studied. Results were discussed and final form was given after necessary corrections. 


\section{Findings}

\section{Length of Residence in Turkey}

The first research question directed to the primary students was: 'How many years have you been in Turkey?' We found out that 10 out of 16 students had been living in Turkey between 3 to 5 years.

\section{The Reason Behind Afghan Students' Happiness in Turkey}

Secondly, the students were asked "Why did you immigrate to Turkey?" The apparent reason for their displacement was to escape from the civil war in Afghanistan. Then the second reason was the limited access to good education. In addition, they affirm that the discriminatory attitudes of both the community members and the government officials regarding girls and women participation in education in Afghanistan has played a crucial role in their decision to leave their country.

\section{Students' Views on Returning to Afghanistan}

Most of the students (S1, S2, S4, S5, S6, S9, S10, S11, S12, S13, S14, S16,) stated that, they did not want to return to their country because they had bad memories about the time they lived in Afghanistan or the stories they heard from their parents about the civil war. But a few of them (S3, S7, S8) want to return to their country in case the war ends and their country become a peaceful country like Turkey.

\section{Patriotism in Students' Drawings}

In this part to identify the emotion that reflects the first impressions of the students, they were asked to draw it in limited time and without using paint materials and to explain what they draw. The students' drawings and explanations included three sub-themes as Beautiful School, Turkish Flag, and Free and strong Turkey. One more than half the total of students' drawings (S1, S2, S3, S4, S6, S7, S9, S13, S15) fell into the theme of beautiful school. The six of them (S8, S10, S11, S12, S14, S16) were collected under the theme of Turkish flag and the last one (S5) was included in the theme of free and strong Turkey. 


\section{The students' Opinion on the Turkish National Anthem}

The students were asked if they knew the lyrics of Turkish national anthem by heart and if they could recite the lyrics. The students said that they could recite one or two out of ten stanzas. It was seen that the students started to learn the Turkish national anthem, which is considered as one of the national values of Turkey, and they were able to recite the parts that they had memorized.

\section{Value of Patriotism in the Description of the Students}

The students' definition of patriotism, becoming a martyr for the motherland (S1, S16), doing one's duty for the motherland (S1, S3, S5, S9, S16) love for Turkey (S5, S6, S9, S11, S13) are grouped into three sub-themes as well. In addition, an extremely interesting finding was that some students (S1, S5) emphasized the role of Ataturk, the founder of Turkish Republic in Turkish history and they associated him with the sultans of Ottoman Empire stating that he protected and saved his country just like the sultans used to do. This finding can be considered as the positive effects of the education given at school.

\section{Result}

As a consequence, almost all the primary students' have forgotten their own cultural identity thus have no sense of attachment to their homeland since they were not born in Afghanistan in addition to the absence of memories related to Afghanistan. Afghan refugees are one of the largest and longest-standing displaced populations in the world some of whom are forced to flee to Turkey as well as to other countries of asylum by circumstances of force majeure. The same students declared that they lead a peaceful life in Turkey thanks to their teachers' and friends' positive attitude and because their host country provides them effective training and education. All in all, they have positive feelings about Turkey and the Turkish people. One of the most important findings of the research is Afghan students in question have begun to embrace Turkey as their homeland. 